\title{
Methyl jasmonate modulation reduces photosynthesis and induces synthesis of phenolic compounds in sweet potatoes subjected to drought
}

\author{
Camila Hatsu Pereira Yoshida1* (D), Ana Cláudia Pacheco ${ }^{1}$ (D), Allan de Marcos Lapaz² (D), Pedro \\ Henrique Gorni ${ }^{3}$ (D) Hilton Fabrício Vítolo ${ }^{1}$ (D) Suzana Chiari Bertoli ${ }^{1}$ (D) \\ 1. Universidade do Oeste Paulista - Centro de Estudos em Ecofisiologia Vegetal do Oeste Paulista - Presidente Prudente \\ (SP), Brazil. \\ 2. Universidade Estadual Paulista “Júlio de Mesquita Filho" - Faculdade de Engenharia - Departamento de Biologia e \\ Zootecnia - Ilha Solteira (SP), Brazil. \\ 3. Faculdades Gammon - Departamento de Agronomia - Paraguaçu Paulista (SP), Brazil.
}

\begin{abstract}
Sweet potato [Ipomoea batatas (L.) Lam.] has wide adaptability to different climatic conditions. However, its yield can be affected by prolonged periods of drought. Application of exogenous jasmonates can modulate several physiological and biochemical processes, improving plant tolerance to abiotic stress. This study sought to evaluate the role of exogenous application of methyl jasmonate (MeJA) in attenuating the adverse effects of drought stress by physiobiochemical analyses and their impact during the early initiation of tuberous roots. The experimental design was completely randomized and arranged in a $2 \times 2$ factorial, comprised of two concentrations of a MeJA plant regulator [without $\left(0 \mu \mathrm{mol} \cdot \mathrm{L}^{-1}\right)$ and with $\left(13 \mu \mathrm{mol} \cdot \mathrm{L}^{-1}\right)$ application] and two water regimes (optimum and drought conditions, corresponding to a field capacity of 100 and $40 \%$, respectively). Plants treated with MeJA showed a reduction in total leaf area and leaf dry biomass but increased adventitious root dry biomass. In addition, MeJA application in sweet potato plants affected photosynthetic performance and increased and antioxidant phenolic compounds, carotenoids, anthocyanins, and proline. The evaluated response mechanisms showed that the severity of drought was more prominent than the positive effects of MeJA, since the increases on antioxidant pigments and secondary metabolites were not sufficient to mitigate stress caused by drought, which was reflected in the reduced tuberous root production.
\end{abstract}

Key words: photosynthetic performance, phenylalanine ammonia lyase, tuberous roots, Ipomoea batatas (L.).
Received:

Apr. 9, 2020

Accepted:

May 21, 2020

Section Editor:

Mauro Guida dos Santos

*Corresponding author: camilahatsu@gmail.com

\section{INTRODUCTION}

Ipomoea batatas (L.) Lam. (sweet potato) is a starchy tuberous root containing several vitamins, minerals, and proteins (Shigematsu et al. 2017), which is why it is one of the seven major food crops cultivated worldwide (Li et al. 2018). Recent research has reported that sweet potato, when included in the human diet, is beneficial for preventing many diseases (Esatbeyoglu et al. 2017), making it a functional food. This is due to high contents of polyphenolic compounds and carotenoids (Albishi et al. 2013; Esatbeyoglu et al. 2017; Wang et al. 2018).

Despite its rusticity, easy maintenance, short crop cycle, resistance to diseases and pests, wide adaptation to arid and dry regions, and high yield potential, sweet potato yield is affected in regions exposed to strict drought regimes (Mbinda et al. 2016; 2018), particularly during the establishment phase, including early vine development and storage root initiation 
(Gajanayake et al. 2014). The formation of tuberous roots in sweet potatoes can begin within four weeks after planting the branch, depending on the cultivar and environmental conditions. In this phase it is ideal to have favorable conditions in terms of soil moisture and temperature (Gajanayake and Reddy 2016).

Jasmonic acid and its methyl ester methyl jasmonate (MeJA) are considered plant regulators that occur naturally in plants and control morphological, physiological, and biochemical processes (Ueda and Saniewski 2006; Norastehnia et al. 2007). Both are involved in signal transduction pathways in plant responses to environmental stressors. The exogenous application of jasmonates can modulate several physiological responses that lead to increased resistance to abiotic stress (Walia et al. 2007). The application of plant regulators such as salicylic acid, MeJA, and abscisic acid in sweet potato increases the levels of antioxidant compounds, including phenolics, flavonoids, anthocyanins, and $\beta$-carotene (Ghasemzadeh et al. 2016). Plants exhibiting increased synthesis of polyphenols under abiotic stress usually show better adaptability to limiting environments, since these compounds have antioxidative properties and are capable of scavenging free radicals, protecting plant cells from negative effects of oxidative stress (Sharma et al. 2016).

The hypothesis of this work is that the exogenous application of MeJA modulates the protection mechanisms against drought, increasing production of phenolic compounds in sweet potato leaves and roots. Thus, this study sought to evaluate the role of exogenous application of MeJA in attenuating the adverse effects of drought stress by physiobiochemical analyses and their impact during the early initiation of tuberous roots.

\section{MATERIAL AND METHODS}

\section{Experimental site}

The experiment was carried out at the University of Western São Paulo (UNOESTE), Presidente Prudente, State of São Paulo, Brazil (22 $06^{\prime} 59^{\prime \prime} \mathrm{S}$ and $51^{\circ} 27^{\prime} 12^{\prime \prime} \mathrm{W} ; 402 \mathrm{~m}$ above sea level). The experiment was conducted in a semicontrolled greenhouse environment (temperature and humidity), between November 2018 and January 2019.

\section{Design and experimental treatments}

The experimental design was completely randomized with 10 replications and arranged in a $2 \times 2$ factorial scheme, comprising two concentrations of a MeJA plant regulator [without $\left(0 \mu \mathrm{mol} \cdot \mathrm{L}^{-1}\right)$ and with $\left(13 \mu \mathrm{mol} \cdot \mathrm{L}^{-1}\right)$ application] in combination with two water regimes (optimum and drought conditions, which correspond to field capacity at 100 and $40 \%$, respectively). The plots were composed of 40 pots with one plant each. Twenty-four pots were used for photosynthetic, biochemical, biometric and yield evaluation. The remaining 16 pots were used to evaluate leaf water potential and discarded at the end of the experiment.

\section{Cultivation conditions}

A mixed soil of dystrophic ultisol (Santos et al. 2018) was used with a Carolina - XVI substrate, in the ratio 2:1, respectively. The Carolina - XVI substrate used was composed of peat, vermiculite, and limestone.

The soil was collected at a 0.0-0.2 $\mathrm{m}$ depth. It was crumbled, air-dried and sieved $(4.0 \mathrm{~mm})$ and shown the following chemical attributes: $\mathrm{pH}\left(\mathrm{CaCl}_{2}\right) 4.2$, organic matter $3 \mathrm{~g} \cdot \mathrm{dm}^{-3}, \mathrm{P}\left(\right.$ resin) $3 \mathrm{mg} \cdot \mathrm{dm}^{-3}, \mathrm{~K} 1.36 \mathrm{mmol}_{\mathrm{c}} \cdot \mathrm{dm}^{-3}, \mathrm{Ca} 4.53 \mathrm{mmol} \cdot \mathrm{dm}^{-3}$, $\mathrm{Mg} 3.26 \mathrm{mmol}_{\mathrm{c}} \cdot \mathrm{dm}^{-3}, \mathrm{~S} 10.73 \mathrm{mg} \cdot \mathrm{dm}^{-3}$, B $0.29 \mathrm{mg} \cdot \mathrm{dm}^{-3}, \mathrm{Cu} 0.6 \mathrm{mg} \cdot \mathrm{dm}^{-3}, \mathrm{Fe} 2.97 \mathrm{mg} \cdot \mathrm{dm}^{-3}, \mathrm{Mn} 1.13 \mathrm{mg} \cdot \mathrm{dm}^{-3}, \mathrm{Zn} 0.23 \mathrm{mg} \cdot \mathrm{dm}^{-3}$, potential acidity $(\mathrm{H}+\mathrm{Al}) 21.83 \mathrm{mmol} \cdot \mathrm{dm}^{-3}, \mathrm{Al} 7.97 \mathrm{mmol}_{c} \cdot \mathrm{dm}^{-3}$, sum of bases $9.15 \mathrm{mmol}_{c} \cdot \mathrm{dm}^{-3}$, cation exchange capacity $30.98 \mathrm{mmol}_{\mathrm{c}} \cdot \mathrm{dm}^{-3}$, and base saturation $29.5 \%$. Based on the chemical analysis, soil liming was carried out to raise the base saturation to $70 \%$ (Quaggio et al. 1985), by the addition of $750 \mathrm{mg} \cdot \mathrm{dm}^{-3}$ dolomitic limestone $\left(36 \% \mathrm{CaCO}_{3}\right.$ and $15.8 \% \mathrm{MgCO}_{3}$ ). The soil containing carbonate salts was incubated for 30 days in pots at a humidity of $80 \%$ at field capacity to allow it to equilibrate. 


\section{Experimental process}

Fertilization was carried out with $1 \mathrm{mg} \cdot \mathrm{dm}^{-3}$ of the formulation 4-30-10 (N-P-K). After 7 days, slips of sweet potato cultivar Beauregard $\left(20 \pm 1 \mathrm{~cm}\right.$ ) were transplanted to pots (one slip per pot) with a capacity of $8 \mathrm{dm}^{3}$ at a depth of $10 \mathrm{~cm}$, which were cultivated for a period of 5 weeks for adventitious root formation. Cover fertilization with $0.42 \mathrm{mg} \cdot \mathrm{dm}^{-3}$ of the formulation 20-05-20 (N-P-K) was done in the 4th week.

After the initial acclimatization period, plants were standardized for length of the branch (approximately $40 \pm 1 \mathrm{~cm}$ in length) and number of leaves (approximately 12 leaves per branch), selecting those with greater vigor and homogeneity of size.

\section{MeJA application and water deficit imposition}

Before subjecting the plants to drought, field capacity of the soil [100\% water mass (g) that the soil supports] was determined. The water deficit was imposed 37 days after slip transplantation, coincided with the tuberization start period. Plants remain in this condition for 9 days (Yooyongwech et al. 2013), that is, until 46 days after slip transplantation, with a daily replacement up to $40 \%$ of field capacity, based on Gajanayake and Reddy (2016). Under optimum water conditions, plants were watered daily to field capacity. During this period, the mass of each pot was measured once a day, in the morning, and the volume of water lost by evapotranspiration was restored.

Methyl jasmonate application (224.30 MW, Sigma) was performed at a concentration of $13 \mu \mathrm{mol} \cdot \mathrm{L}^{-1}$ (Ghasemzadeh et al. 2016). Methyl jasmonate application was performed via manual foliar pulverization one day before and on the $5^{\text {th }}$ day of water deficit imposition (50 $\mathrm{mL}$ of the solution per plant).

\section{Measurements of gas exchange}

On the $3^{\text {rd }}, 6^{\text {th }}$, and $9^{\text {th }}$ day of water deficit imposition, gas exchange evaluations were carried out using a portable infrared gas analyzer (IRGA, Li-6400XTR, LiCor, EUA) by choosing two leaves from each plant between the sixth and ninth fully developed leaf of the branch. Evaluations were carried out on a clear day between 10:00 a.m. and 12:00 p.m. Photosynthetically active radiation (PAR) was standardized to an artificial saturating light of $1200 \mu \mathrm{mol} \cdot \mathrm{m}^{-2} \cdot \mathrm{s}^{-1}$ and the concentration of $\mathrm{CO}_{2}$ was established at $380 \pm 10 \mu \mathrm{mol} \cdot \mathrm{mol}^{-1}$. The average relative humidity, the temperature and the vapor pressure deficit were $50 \%, 26 \pm 2{ }^{\circ} \mathrm{C}$ and $2.22 \pm 0.47 \mathrm{kPa}$, respectively.

The net photosynthetic rate $\left(A, \mu \mathrm{mol} \mathrm{CO} \cdot \mathrm{m}^{-2} \cdot \mathrm{s}^{-1}\right)$, stomatal conductance $\left(g s, \mathrm{~mol} \mathrm{H}_{2} \mathrm{O} \cdot \mathrm{m}^{-2} \cdot \mathrm{s}^{-1}\right)$, internal concentration of $\mathrm{CO}_{2}$ in the substomatic chamber $\left(\mathrm{Ci}, \mu \mathrm{mol} \mathrm{CO} \mathrm{CO}_{2} \mathrm{~mol} \cdot \mathrm{ar}^{-1}\right)$, transpiration rate $\left(E, \mathrm{mmol} \mathrm{H}_{2} \mathrm{O} \cdot \mathrm{m}^{-2} \cdot \mathrm{s}^{-1}\right)$, water use efficiency [WUE, $\left.(A / E) \mu \mathrm{mol} \mathrm{CO} \cdot \mathrm{mmol}^{-1} \mathrm{H}_{2} \mathrm{O}\right]$, and instantaneous carboxylation efficiency $\left[\mathrm{EiC},(\mathrm{A} / \mathrm{Ci}) \mathrm{mol} \cdot \mathrm{air}^{-1}\right]$ were obtained.

\section{Measurements of leaf water potential $(\Psi w)$}

The evaluation days were the same as those described in gas exchange measurements. Two leaves from each plant were chosen between the sixth and ninth fully developed leaf of the branch and measurements were recorded at 12:00 p.m. Measurements were made in a pressure chamber (model 1000, PMS Instruments, USA), expressed in MPa (Scholander et al. 1965).

\section{Material storage for biochemical analysis}

46 days after slip transplantation, leaves were collected between the sixth and ninth fully developed leaf of the branch (counting down from the apex) of each plant and immediately immersed in liquid $\mathrm{N}_{2}$ for rapid freezing. The material was stored at $-80^{\circ} \mathrm{C}$ for further analysis. 


\section{Analysis of photosynthetic and antioxidant pigments}

Methods for determining chlorophyll $a$ (Chl $a)$, chlorophyll $b(\mathrm{Chl} b)$, total chlorophyll (Tchl), and carotenoid contents (CAR) were based on those described by Hiscox and Israelstam (1979). Fresh leaf tissue (0.1 g) was incubated in a water bath at $65^{\circ} \mathrm{C}$ for $1 \mathrm{~h}$ containing $7 \mathrm{~mL}$ of DMSO. After that time, the samples were cooled in the dark until they reached room temperature. The readings were performed in a spectrophotometer at 663, 645 and $480 \mathrm{~nm}$. Photosynthetic pigment content was calculated following the equation used by Arnon (1949) and expressed in $\mu \mathrm{g} \cdot \mathrm{g}^{-1} \mathrm{FW}$.

Anthocyanins were determined according to Francis (1982). Fresh leaf tissue (1 g) was macerated in a 95\% ethanol extract solution acidified with $1.5 \mathrm{~N} \mathrm{HCl}$ and stayed for $24 \mathrm{~h}$ at a temperature of $5{ }^{\circ} \mathrm{C}$. The absorbance was read at $535 \mathrm{~nm}$ using a spectrophotometer (BEL Engineering, model UV-M51) and the resulted was expressed in $\mu \mathrm{g} \cdot 100^{-1} \mathrm{~g} \mathrm{FW}$.

For determination of the $\beta$-carotene content, fresh (leaves and roots) tissue $(5 \mathrm{~g})$ were ground and packed in a volumetric flask to protect from light. Then, $50 \mathrm{~mL}$ of a 2:1:1 hexane, acetone, and ethanol mixture was added to solubilize the carotenoids (Sadler et al. 1990). The samples were stirred for $30 \mathrm{~min}$ and $10 \mathrm{~mL}$ of distilled water was added. The solution was allowed to separate into a distinct polar layer $(35 \mathrm{~mL})$ and a nonpolar layer $(25 \mathrm{~mL})$. The absorbance was read at $450 \mathrm{~nm}$ using a spectrophotometer and expressed in $\mu \mathrm{g} \cdot \mathrm{g}^{-1} \mathrm{FW}$, calculated according to the equation by Craft and Soares Junior (1992).

\section{Polyphenolic compounds and phenylalanine ammonia lyase enzyme activity (PAL, EC 4.3.1.5) assay}

The ethanolic crude extracts obtained were performed according to the method by Simões et al. (2007). Total polyphenolic content of leaves (TPL) and roots (TPR) were determined according to the Folin-Ciocalteau reagent method. The samples $(25 \mu \mathrm{L})$ were mixed with $125 \mu \mathrm{L}$ of Folin-Ciocalteau reagent, $350 \mu \mathrm{L}$ of $25 \%$ sodium carbonate solution and $2 \mathrm{~mL}$ of water (Stagos et al. 2012). The mixture was incubated for $1 \mathrm{~h}$ at room temperature. Absorbance was read at $765 \mathrm{~nm}$ and the result was expressed in $\mu \mathrm{g} \cdot \mathrm{mL}^{-1}$ of gallic acid equivalent (GAE). The total flavonoid content of leaves (TFL) and roots (TFR) was measured according to the method by Yao et al. (2013). The samples $(100 \mu \mathrm{L})$ were mixed with $400 \mu \mathrm{L}$ of ethanol $70 \%$, $50 \mu \mathrm{L}$ of $\mathrm{NaNO}_{2}(5 \%), 50 \mu \mathrm{L}$ of $\mathrm{AlCl}_{3}(10 \%), 300 \mu \mathrm{L}$ of NaOH $\left(1 \mathrm{~mol} \cdot \mathrm{L}^{-1}\right)$ and $100 \mu \mathrm{L}$ of water. The mixture was incubated for 15 minutes in the dark. Absorbance was read at $510 \mathrm{~nm}$ and the result was expressed in $\mu \mathrm{g} \cdot \mathrm{mL}^{-1}$ of rutin equivalent (RE).

The enzymatic activity of PAL (EC 4.3.1.5) was evaluated according to Hyodo et al. (1978). Phenylalanine ammonia lyase enzyme activity was assayed by following (E)-cinnamic acid formation at $290 \mathrm{~nm}$ in a spectrophotometer at $40{ }^{\circ} \mathrm{C}$ in buffer (0.5 M TRIS-EDTA, either $\mathrm{pH} 8.5$ ) containing $30 \mu \mathrm{mol} \cdot \mathrm{L}^{-1} \mathrm{~L}$-phenylalanine. A molar extinction coefficient of $104 \mathrm{mmol} \cdot \mathrm{L}^{-1} \cdot \mathrm{cm}^{-1}$ (Zucker 1965) was used for calculation. The results were expressed in Kat $\cdot \mathrm{sec}^{-1} \cdot \mathrm{mg}^{-1}$ protein. The protein content was determined, as described by Bradford (1976), using bovine serum albumin as a standard.

\section{Malondialdehyde (MDA) and leaf proline content evaluation}

Lipid peroxidation was determined by the production of 2-thiobarbituric acid (TBA)-reactive substances, especially MDA, according to Heath and Packer (1968). Fresh leaf tissue $(0.25 \mathrm{~g})$ was ground in liquid $\mathrm{N}_{2}$ with a pestle and mortar, to which $3 \mathrm{~mL}$ of $0.1 \%$ trichloroacetic acid (TCA) in $20 \%$ polyvinyl polypyrrolidone (PVPP) was added. After complete homogenization, the samples were centrifuged at $10,000 \mathrm{rpm}$ for $10 \mathrm{~min}$ at $4{ }^{\circ} \mathrm{C} .0 .25 \mathrm{~mL}$ of supernatant was added to $1 \mathrm{~mL}$ $20 \%$ TCA solution containing $0.5 \%$ thiobarbituric acid (TBA). The samples were kept in a dry bath at $95{ }^{\circ} \mathrm{C}$ for $30 \mathrm{~min}$ and then on ice for $20 \mathrm{~min}$. Subsequently, the samples were centrifuged at 10,000 rpm for $5 \mathrm{~min}$. Samples were read at two wavelengths, 535 and $600 \mathrm{~nm}$ and the resulted was expressed as nmol.g-1 $\mathrm{FW}$.

Proline content in leaf tissues was measured via reaction with ninhydrin (Bates et al. 1973). Fresh leaf tissue (0.5 g) was ground in $5 \mathrm{~mL}$ of $3 \%$ sulphosalicylic acid and centrifuged at $13,000 \mathrm{rpm}$ for $10 \mathrm{~min}$ at $4{ }^{\circ} \mathrm{C}$. Two milliliters of supernatant was incubated with equal volume of acid ninhydrin and glacial acetic acid at $100^{\circ} \mathrm{C}$ for $1 \mathrm{~h}$. The reaction mixture was extracted with $2 \mathrm{~mL}$ toluene and the chromophore containing toluene was aspirated, cooled to room temperature, and the absorbance was read at $520 \mathrm{~nm}$ with a spectrometer using L-proline as a standard. Proline content was expressed as $\mu \mathrm{mol} \cdot \mathrm{g}^{-1} \mathrm{FW}$. 


\section{Partitioned biomass production}

46 days after slip transplantation, plants were separated into the shoot (leaves and stems) and roots (adventitious and tuberous). Roots with a diameter equal to or greater than $5 \mathrm{~mm}$ were considered tuberous roots (Villordon et al. 2009). Total leaf area (TLA, $\mathrm{cm}^{2}$ ) was measured using a portable area meter (model LI - 3000A, LI-COR, USA). The number of tuberous roots (NTR) and diameter of the tuberous roots (DTR) was determined with a digital caliper and were expressed in $\mathrm{mm}$. Subsequently, the material was placed in an oven with air circulation at $65{ }^{\circ} \mathrm{C}$ for $72 \mathrm{~h}$ to measure the leaf (LDB), steam (SDB), total shoot (TSDB), tuberous root (TUDB), adventitious root (ARDB), and total root (TRDB) dry biomass, expressed in g.plant ${ }^{-1}$.

\section{Statistical analysis}

In all considered datasets, normality of the data was analyzed using the Anderson-Darling test and homoscedasticity of the data was verified with Levenn's test, both at 0.05 probability. Data were subjected to analysis of variance (ANOVA) using the $\mathrm{F}$ test $(\mathrm{p} \leq 0.05)$. When significant, the traits were subjected to the Tukey's test $(\mathrm{p}<0.05)$. All statistical analysis of the data was performed using protocols developed in the R software (R Development Core Team 2019).

\section{RESULTS}

\section{Gas exchange and leaf water potential}

On the $3^{\text {rd }}, 6^{\text {th }}$, and $9^{\text {th }}$ day, all gas exchange traits and $\Psi w$ showed an isolated effect for drought (Table S1). On these same days, $A$ and $C i$ showed an isolated effect for MeJA, while the $E$ showed a significant effect only on the $6^{\text {th }}$ and $9^{\text {th }}$ day. Plants cultivated under drought showed reductions in $A, g s, C i, E$, and $\Psi w$ on the $3^{\text {rd }}, 6^{\text {th }}$, and $9^{\text {th }}$ day (Table 1 ).

Plants treated with MeJA decreased $A$ by 15,22 , and $30 \%$ and increased $C i$ by 15,9 , and $4 \%$, on the $3^{\text {rd }}, 6^{\text {th }}$, and $9^{\text {th }}$ day, respectively. The $g s$ and $\Psi w$ were unchanged in plants treated with MeJA on the $3^{\text {rd }}, 6^{\text {th }}$, or $9^{\text {th }}$ day. The same behavior was observed in $E$, but only on the $3^{\text {rd }}$ day. On the $6^{\text {th }}$ and $9^{\text {th }}$ day, $E$ showed a reduction of $18 \%$ (Table 1 ).

Table 1. Results for $\mathrm{CO}_{2}$ assimilation rate $\left(A, \mu \mathrm{mol} \mathrm{CO} \cdot \mathrm{m}^{-2} \cdot \mathrm{s}^{-1}\right)$, stomatal conductance $\left(\mathrm{gs}, \mu \mathrm{mol} \mathrm{CO}_{2} \cdot \mathrm{m}^{-2} \cdot \mathrm{s}^{-1}\right)$, internal $\mathrm{CO}_{2}$ concentration in the substomatic chamber $\left(C i, \mu \mathrm{mol} \mathrm{CO} \cdot \mathrm{m}^{-2}\right.$ air $\left.{ }^{-1}\right)$, transpiration rate $\left(E, \mathrm{mmol} \mathrm{H}_{2} \mathrm{O} \cdot \mathrm{m}^{-2} \cdot \mathrm{s}^{-1}\right)$, and water potential $(\Psi \mathrm{w}, \mathrm{MPa})$ evaluated on the $3^{\text {rd }}, 6^{\text {th }}$, and $9^{\text {th }}$ day in sweet potato 'Beauregard' treated with two concentrations of a MeJA plant regulator [without $\left(0 \mu \mathrm{mol} \cdot \mathrm{L}^{-1}\right)$ and with $\left(13 \mu \mathrm{mol} \cdot \mathrm{L}^{-1}\right)$ application] in combination with two water regimes (optimum and drought conditions, which correspond to field capacity at 100 and $40 \%$, respectively).

\begin{tabular}{|c|c|c|c|c|c|c|c|}
\hline Days of stress & Factors & Levels & $A$ & gs & $\mathrm{Ci}$ & $E$ & $\Psi w$ \\
\hline \multirow{4}{*}{$3^{\text {rd }}$} & \multirow{2}{*}{ Water regime } & Optimum & $23.71 a$ & $0.79 a$ & $373.28 a$ & $11.06 a$ & $-0.55 a$ \\
\hline & & Drought & $0.81 b$ & $0.02 b$ & $304.01 b$ & $0.63 b$ & $-0.90 b$ \\
\hline & \multirow{2}{*}{ MeJA } & Without & $13.23 \mathrm{~A}$ & 0.42 & 315.09B & 5.98 & -0.73 \\
\hline & & With & 11.29B & 0.39 & $362.20 \mathrm{~A}$ & 5.72 & -0.71 \\
\hline \multirow{4}{*}{$6^{\text {th }}$} & \multirow{2}{*}{ Water regime } & Optimum & $27.42 a$ & $0.78 a$ & $353.20 a$ & $9.10 a$ & $-0.50 a$ \\
\hline & & Drought & $2.56 b$ & $0.07 b$ & $298.35 b$ & $1.23 b$ & $-0.94 b$ \\
\hline & \multirow{2}{*}{ MeJA } & Without & $13.23 \mathrm{~A}$ & 0.42 & 315.09B & 5.98 & -0.73 \\
\hline & & With & $11.29 B$ & 0.39 & $362.20 \mathrm{~A}$ & 5.72 & -0.71 \\
\hline \multirow{4}{*}{$9^{\text {th }}$} & \multirow{2}{*}{ Water regime } & Optimum & $22.18 a$ & $0.67 a$ & $315.06 a$ & $9.28 a$ & $-0.52 a$ \\
\hline & & Drought & $3.30 \mathrm{~b}$ & $0.05 b$ & $292.00 b$ & $0.89 \mathrm{~b}$ & $-0.92 b$ \\
\hline & \multirow{2}{*}{ MeJA } & Without & $15.00 \mathrm{~A}$ & 0.44 & $297.00 B$ & $5.58 \mathrm{~A}$ & -0.71 \\
\hline & & With & $10.47 \mathrm{~B}$ & 0.27 & $310.06 \mathrm{~A}$ & $4.59 \mathrm{~B}$ & -0.73 \\
\hline
\end{tabular}

Lowercase letters compare water regimes independent of MeJA, while uppercase letters compare the effect of MeJA independent of the water regime. 
An interaction for water regime and MeJA application was observed in EiC on the $3^{\text {rd }}$ and $6^{\text {th }}$ day and in $W U E$ on $6^{\text {th }}$ day (Table S1). Plants subjected to drought showed reductions in EiC on the $3^{\text {rd }}, 6^{\text {th }}$, and $9^{\text {th }}$ day. Water use efficiency decreased on the $3^{\text {rd }}$ day, but on the $6^{\text {th }}$ day the decrease was only observed in plants treated with MeJA. Conversely, $W U E$ increased on the $9^{\text {th }}$ day (Table 2).

In relation to MeJA application, on the $3^{\text {rd }}, 6^{\text {th }}$, and $9^{\text {th }}$ day, plants showed a reduction in EiC, except under drought on the $3^{\text {rd }}$ day. Water use efficiency was unchanged in plants treated with MeJA on the $3^{\text {rd }}$ day. This behavior was also observed in plants under optimum water conditions on the $6^{\text {th }}$ day. Plants treated with MeJA and cultivated under drought showed a decrease in WUE on the $6^{\text {th }}$ A decrease in WUE was also observed on the $9^{\text {th }}$ day, however this effect was independent of water regime (Table 2).

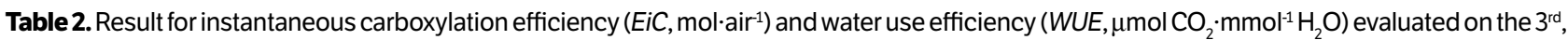
$6^{\text {th }}$, and $9^{\text {th }}$ day in sweet potato 'Beauregard' treated with two concentrations of a MeJA plant regulator [without $\left(0 \mu \mathrm{mol} \cdot \mathrm{L}^{-1}\right)$ and with $\left(13 \mu \mathrm{mol} \cdot \mathrm{L}^{-1}\right)$ application] in combination with two water regimes (optimum and drought conditions, which correspond to field capacity at 100 and $40 \%$, respectively).

\begin{tabular}{|c|c|c|c|c|c|c|c|}
\hline \multirow{3}{*}{ Days of stress } & \multirow{3}{*}{ Water regime } & \multicolumn{3}{|c|}{ EiC } & \multicolumn{3}{|c|}{ WUE } \\
\hline & & \multicolumn{2}{|c|}{ MeJA } & \multirow{2}{*}{ Average } & \multicolumn{2}{|c|}{ MeJA } & \multirow{2}{*}{ Average } \\
\hline & & Without & With & & Without & With & \\
\hline \multirow{3}{*}{$3^{\text {rd }}$} & Optimum & 0.07Aa & 0.06Ba & 0.06 & 2.25 & 2.04 & $2.14 a$ \\
\hline & Drought & $0.00 \mathrm{Ab}$ & $0.00 \mathrm{Ab}$ & 0.00 & 1.04 & 1.16 & $1.10 \mathrm{~b}$ \\
\hline & Average & 0.04 & 0.03 & & 1.65 & 1.60 & \\
\hline \multirow{3}{*}{$6^{\text {th }}$} & Optimum & $0.09 \mathrm{Aa}$ & 0.06Ba & 0.07 & 3.03Aa & $3.05 \mathrm{Aa}$ & 3.04 \\
\hline & Drought & $0.01 \mathrm{Ab}$ & $0.00 \mathrm{Bb}$ & 0.01 & $2.85 \mathrm{Aa}$ & $1.38 \mathrm{Bb}$ & 2.11 \\
\hline & Average & 0.05 & 0.03 & & 2.94 & 2.21 & \\
\hline \multirow{3}{*}{$9^{\text {th }}$} & Optimum & 0.08 & 0.05 & $0.07 a$ & 2.57 & 2.27 & $2.42 \mathrm{~b}$ \\
\hline & Drought & 0.02 & 0.00 & $0.01 b$ & 4.70 & 2.67 & $3.68 a$ \\
\hline & Average & $0.05 \mathrm{~A}$ & $0.03 B$ & & $3.63 \mathrm{~A}$ & 2.47B & \\
\hline
\end{tabular}

Lowercase letters compare the effect of MeJA between different water regimes (columns), while uppercase letters compare the effect of MeJA on the same water regime (rows).

\section{Photosynthetic and antioxidant pigments}

All traits (Chl $a, \mathrm{Chl} b$, Tchl, and CAR) presented in Fig. 1 showed an interaction between water regime and MeJA application (Table S2). Plants cultivated under drought presented marked reductions in Chl $a$, Chl $b$, Tchl, and CAR (Fig. 1).

Plants treated with MeJA showed reduced Chl $a$ (9 and 11\%), Tchl (6 and 9\%), and CAR (29 and 3\%), when cultivated under optimum water conditions or drought, respectively (Figs. 1a and 1c-d). The Chl $b$ was less sensitive and reduced only under drought, decreasing by $3 \%$ (Fig. 1b).

When comparing the behavior of anthocyanins and $\beta$-carotene between water regimes, it was observed that plants under drought showed the lowest TA content (Fig. 2a). Conversely, L $\beta$-car and R $\beta$-car increased in this condition of water supply, with the exception of L $\beta$-car in plants not treated with MeJA (Figs. 2b-c).

Plants treated with MeJA increased TA by $9 \%$ and $10 \%$ and R $\beta$-car by 110 and $9 \%$, when cultivated under optimum water conditions and drought, respectively (Figs. $2 \mathrm{a}$ and $2 \mathrm{c}$ ). The same behavior was observed on L $\beta$-car in plants cultivated under drought, registering an increase of $12 \%$ (Fig. 2b). However, plants cultivated under optimum water conditions showed the opposite behavior, that is, L $\beta$-car was reduced by $13 \%$ when MeJA was applied (Fig. 2 b).

\section{Phenolic compounds and oxidative stress}

All traits (TPL, TPR, TFL, TFR, PAL, MDA, and proline) presented in Figs. 3 and 4 showed an interaction between the water regime and application of MeJA (Table S3. Supplementary material). Plants cultivated under drought showed 

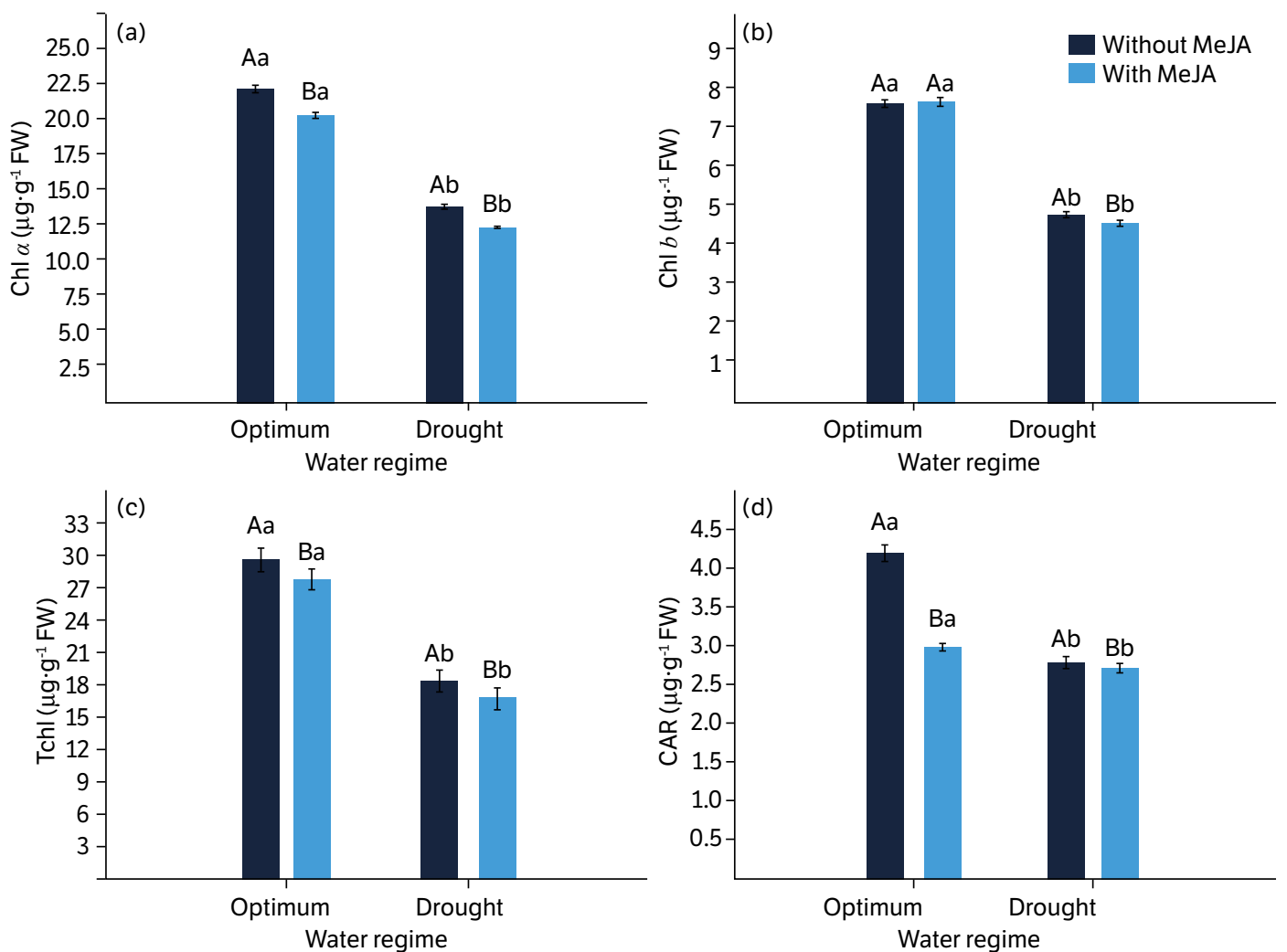

Figure 1. Chlorophyll $a(\mathrm{~A}, \mathrm{Chl} a)$, chlorophyll $b(\mathrm{~B}, \mathrm{Chl} b)$, total chlorophyll (C, Tchl), and carotenoids (D, CAR) on the $9^{\text {th }}$ day in sweet potato 'Beauregard' treated with two concentrations of a MeJA plant regulator [without $\left(0 \mu \mathrm{mol} \cdot \mathrm{L}^{-1}\right)$ and with $\left(13 \mu \mathrm{mol} \cdot \mathrm{L}^{-1}\right)$ application] in combination with two water regimes (optimum and drought conditions, which correspond to field capacity at 100 and $40 \%$, respectively). Lowercase letters compare the effect of MeJA between the water regimes, while uppercase letters compare the MeJA effect on the same water regime. Vertical bars represent the standard error.
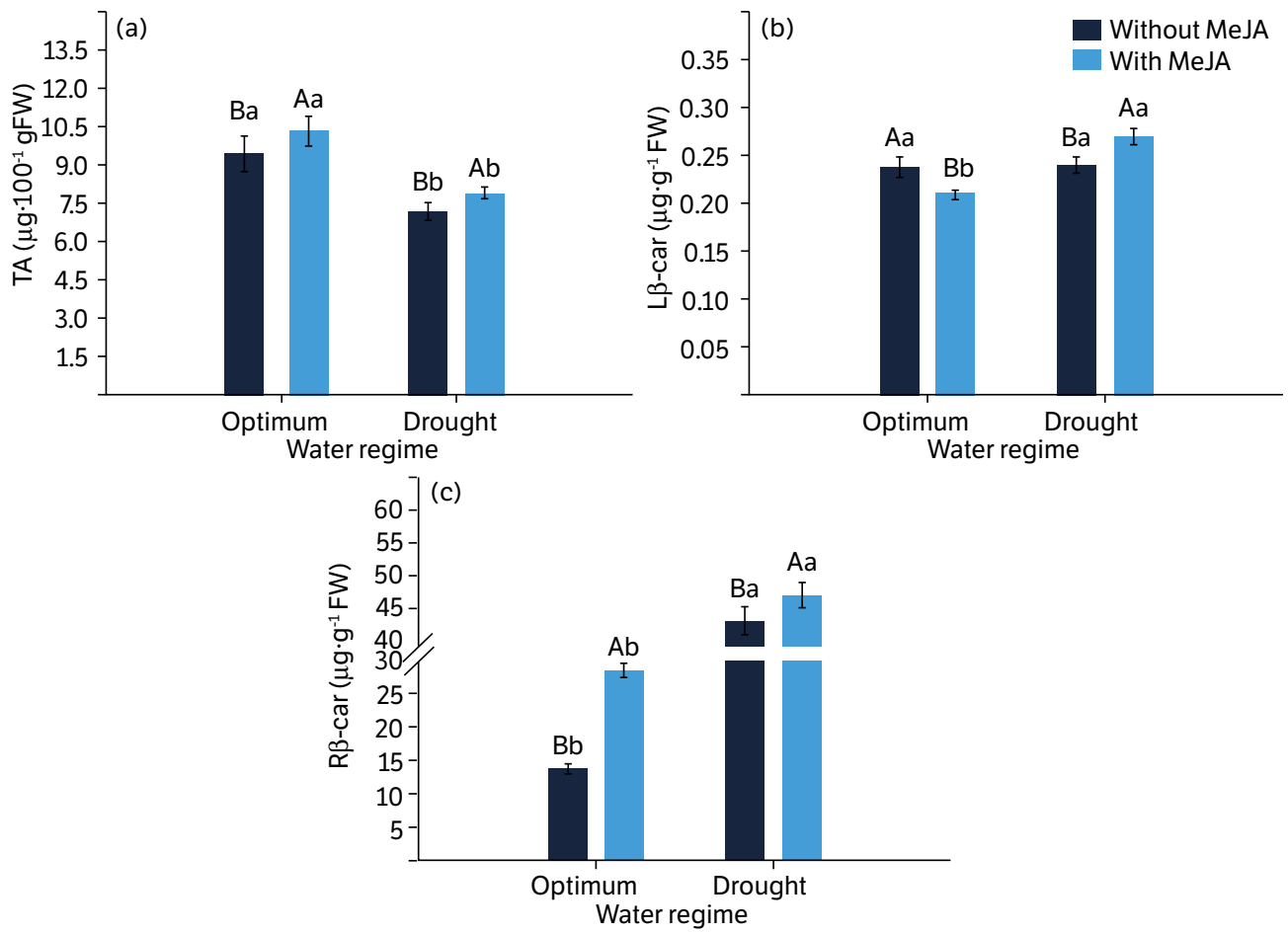

Figure 2. Total anthocyanin (TA, A), leaf $\beta$-carotene $(L \beta-c a r, B)$ and root $\beta$-carotene $(R \beta-c a r, C)$ on the $9^{\text {th }}$ day in sweet potato 'Beauregard' treated with two concentrations of a MeJA plant regulator [without $\left(0 \mu \mathrm{mol} \cdot \mathrm{L}^{-1}\right)$ and with $\left(13 \mu \mathrm{mol} \cdot \mathrm{L}^{-1}\right)$ application] in combination with two water regimes (optimum and drought conditions, which correspond to field capacity at 100 and $40 \%$, respectively. Lowercase letters compare the effect of MeJA between the water regimes, while uppercase letters compare the MeJA effect on the same water regime. Vertical bars represent the standard error. 

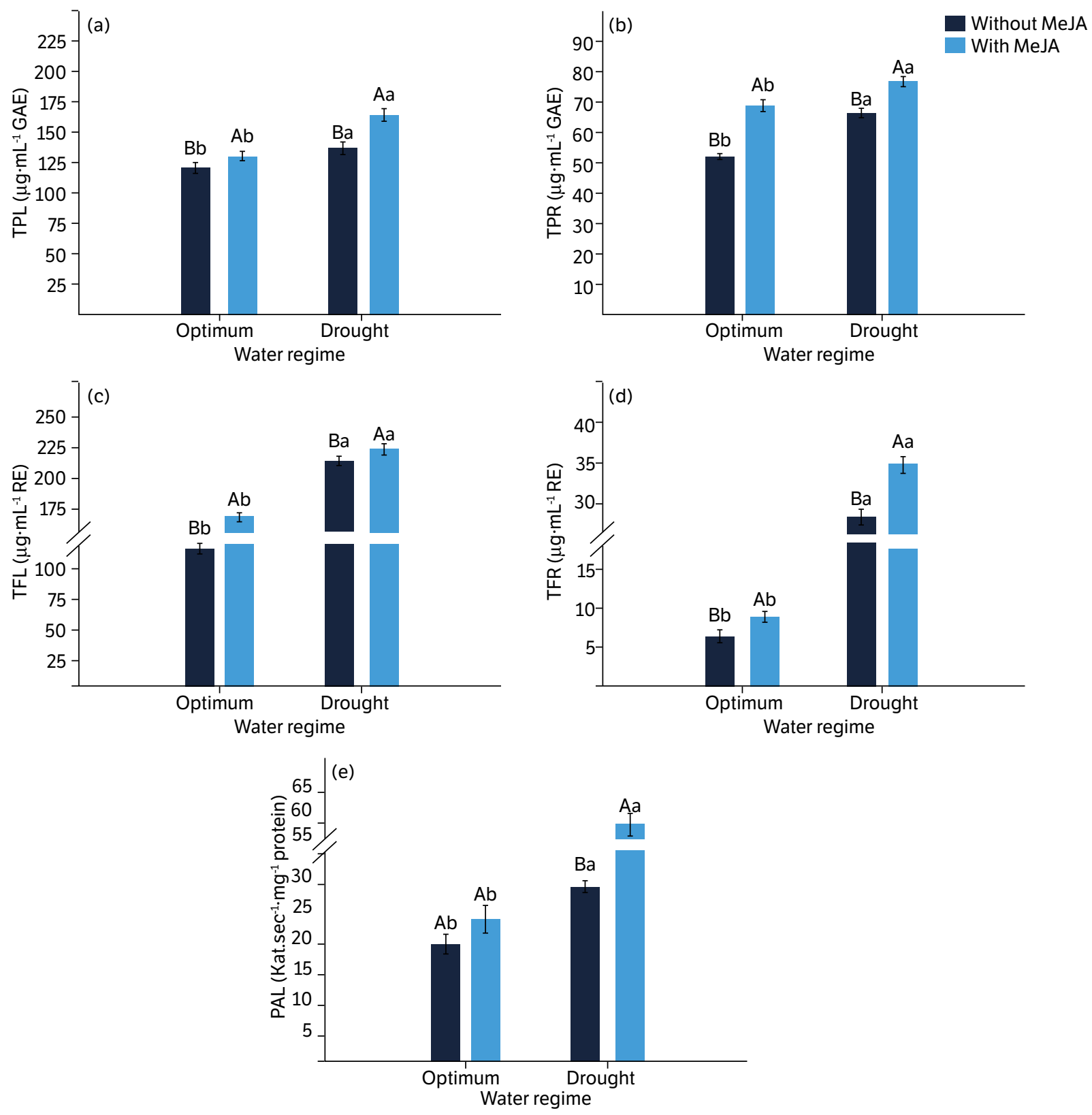

Figure 3. Total polyphenolic in leaf (TPL, A), total polyphenolic in root (TPR, B), total flavonoid in leaf (TFL, C), total flavonoid in root (TFR, D) and activity of the enzyme phenylalanine ammonia lyase (PAL, E) on the $9^{\text {th }}$ day in sweet potato 'Beauregard' treated with two concentrations of a MeJA plant regulator [without $\left(0 \mu \mathrm{mol} \cdot \mathrm{L}^{-1}\right)$ and with $\left(13 \mu \mathrm{mol} \cdot \mathrm{L}^{-1}\right)$ application] in combination with two water regimes (optimum and drought conditions, which correspond to field capacity at 100 and $40 \%$, respectively). Lowercase letters compare the effect of MeJA between the water regimes, while uppercase letters compare the MeJA effect on the same water regime. Vertical bars represent the standard error.

the highest content of TPL, TPR, TFL, and TFR. MeJA application increased the content of these traits, in both water regimes (Figs. 3a-d). Phenylalanine ammonia lyase enzyme activity showed this same behavior, except for plants treated with MeJA when cultivated under optimum water conditions (Fig. 3e).

Plants cultivated under drought showed the highest MDA content (Fig. 4a). Malondialdehyde was lower in plants treated with MeJA, in optimum conditions (-50\%) and under drought stress (-54\%). Plants cultivated under drought conditions and treated with MeJA had an increased proline content (Fig. 4b). 

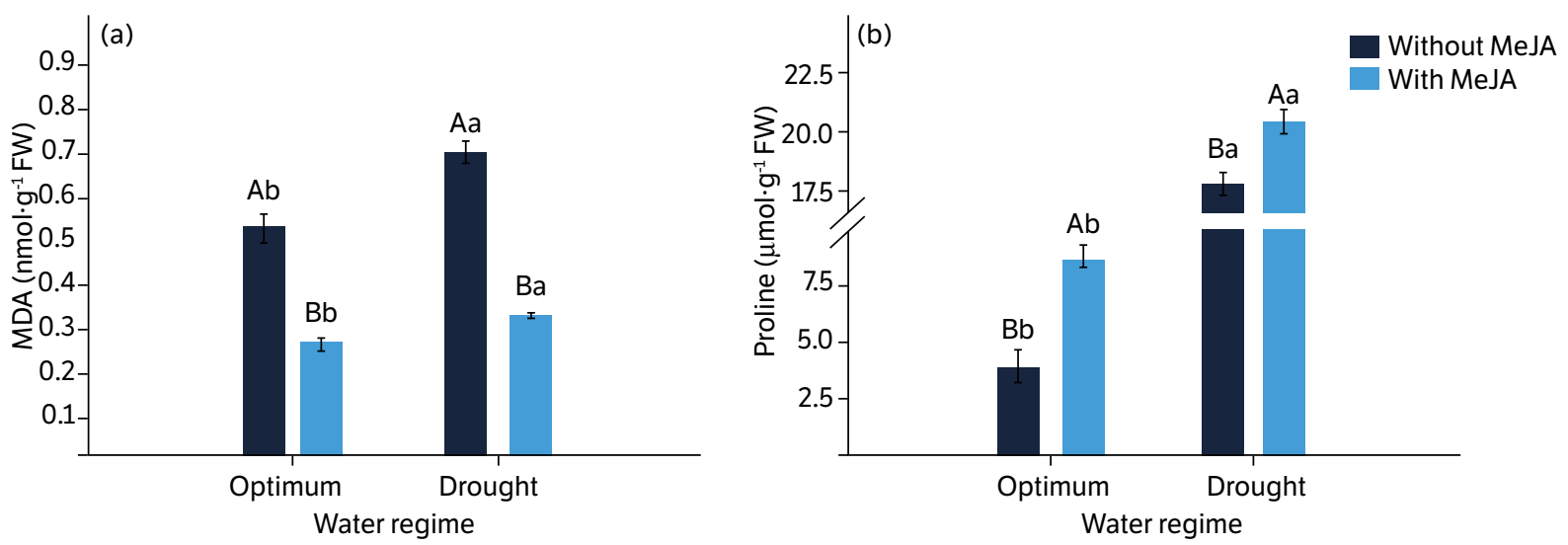

Figure 4. Malondialdehyde (MDA, A) and proline (B) on the $9^{\text {th }}$ day in sweet potato 'Beauregard' treated with two concentrations of a MeJA plant regulator [without $\left(0 \mu \mathrm{mol} \cdot \mathrm{L}^{-1}\right)$ and with $\left(13 \mu \mathrm{mol} \cdot \mathrm{L}^{-1}\right)$ application] in combination with two water regimes (optimum and drought conditions, which correspond to field capacity at 100 and $40 \%$, respectively). Lowercase letters compare the effect of MeJA between the water regimes, while uppercase letters compare the MeJA effect on the same water regime. Vertical bars represent the standard error.

\section{Partitioned biomass production}

The TLA and LDB parameters showed an isolated effect for water regime and MeJA application. The NTU, DTU, SDB, TSDB, TUDB, and TRDB parameters showed an isolated effect for water regime and an effect for MeJA application was detected on ARDB (Table S4). Plants cultivated under drought showed reductions in TLA, NTU, and DTU. Plants treated with MeJA reduced LA by 6\%. (Table 3).

Plants cultivated under drought showed reductions in all assessed dry biomass traits (LDB, SDB, TSDB, TUDB, and TRDB). Plants treated with MeJA showed a reduction of $12 \%$ in LDB; in contrast, there was an increase of $12 \%$ in ARDB (Table 4).

Table 3. Result for total leaf area (TLA, $\mathrm{cm}^{2}$ ), number of tuberous root (NTU, unity·plant ${ }^{-1}$ ) and diameter of tuberous root (DTU, $\mathrm{cm}$ ) evaluated on the $9^{\text {th }}$ day in sweet potato 'Beauregard' treated with two concentrations of a MeJA plant regulator [without $\left(0 \mu \mathrm{mol} \cdot \mathrm{L}^{-1}\right)$ and with $\left(13 \mu \mathrm{mol} \cdot \mathrm{L}^{-1}\right)$ application] in combination with two water regimes (optimum and drought conditions, which correspond to field capacity at 100 and $40 \%$, respectively).

\begin{tabular}{ccccc}
\hline \multirow{2}{*}{ Factors } & Levels & TLA & NTU & DTU \\
\hline \multirow{2}{*}{ Water regime } & Optimum & $5813.82 \mathrm{a}$ & $19.75 \mathrm{a}$ & $1.45 \mathrm{a}$ \\
\cline { 2 - 5 } & Drought & $2400.46 \mathrm{~b}$ & $17.45 \mathrm{~b}$ & $1.19 \mathrm{~b}$ \\
\hline \multirow{2}{*}{ MeJA } & Without & $4223.99 \mathrm{~A}$ & $19.15 \mathrm{~A}$ & $1.35 \mathrm{~A}$ \\
\cline { 2 - 5 } & With & $3990.29 \mathrm{~B}$ & $18.05 \mathrm{~A}$ & $1.30 \mathrm{~A}$ \\
\hline
\end{tabular}

Lowercase letters compare water regimes independent of MeJA, while uppercase letters compare the effect of MeJA independent of the water regime.

Table 4. Tukey's test result for leaf (LDB, $g \cdot$ plant $\left.^{-1}\right)$, steam (SDB, $g \cdot$ plant $\left.^{-1}\right)$ total shoot $\left(T S D B, g \cdot\right.$ plant $\left.^{-1}\right)$, tuberous root $\left(T U D B, g \cdot\right.$ plant $\left.^{-1}\right)$, adventitious root (ARDB, $g \cdot$ plant $^{-1}$ ) and total root dry biomass (TRDB, $g \cdot$ plant $^{-1}$ ) evaluated on the $9^{\text {th }}$ day in sweet potato 'Beauregard' treated with two concentrations of a MeJA plant regulator [without $\left(0 \mu \mathrm{mol} \cdot \mathrm{L}^{-1}\right)$ and with $\left(13 \mu \mathrm{mol} \cdot \mathrm{L}^{-1}\right)$ application] in combination with two water regimes (optimum and drought conditions, which correspond to field capacity at 100 and $40 \%$, respectively).

\begin{tabular}{cccccccc}
\hline Factors & Levels & LDB & SDB & TSDB & TUDB & ARDB & TRDB \\
\hline \multirow{2}{*}{ Water regime } & Optimum & $18.50 \mathrm{a}$ & $25.70 \mathrm{a}$ & $44.2 \mathrm{a}$ & $67.36 \mathrm{a}$ & $33.43 \mathrm{a}$ & $100.80 \mathrm{a}$ \\
\cline { 2 - 8 } & Drought & $9.50 \mathrm{~b}$ & $17.40 \mathrm{~b}$ & $26.9 \mathrm{~b}$ & $48.64 \mathrm{~b}$ & $35.45 \mathrm{a}$ & $84.10 \mathrm{~b}$ \\
\hline \multirow{2}{*}{ MeJA } & Without & $14.90 \mathrm{~A}$ & $22.30 \mathrm{~A}$ & $37.90 \mathrm{~A}$ & $61.05 \mathrm{~A}$ & $31.23 \mathrm{~B}$ & $92.20 \mathrm{~A}$ \\
\cline { 2 - 8 } & With & $13.10 \mathrm{~B}$ & $20.80 \mathrm{~A}$ & $33.90 \mathrm{~A}$ & $54.96 \mathrm{~A}$ & $37.64 \mathrm{~A}$ & $92.60 \mathrm{~A}$ \\
\hline
\end{tabular}

Lowercase letters compare water regimes independent of MeJA, while uppercase letters compare the effect of MeJA independent of the water regime. 


\section{DISCUSSION}

\section{Gas exchanges and water potential}

In plants treated with MeJA, reductions were observed in $A$, however $g s$ was not altered, which shows that the reduction in $A$ was due to cumulative limitations in carboxylation reactions (i.e., biochemical limitations), as verified by the lower EiC (Tables 1 and 2). According to Jung (2004) and Springer et al. (2015), jasmonic acid and MeJA applied exogenously led to decreased expression of genes related to photosynthesis, such as the gene encoding the small subunit of ribulose-1.5bisphosphate carboxylase/oxygenase (Rubisco). The reduction in translation and increase in the degradation of Rubisco were accompanied by a rapid loss of chlorophyll in barley leaves (Weidhase et al. 1987). There was also a reduction in WUE on the $9^{\text {th }}$ day of water deficit imposition, which is due to a substantial reduction in $A$ (Tables 1 and 2).

Traits $A, g s, C i$, and $E$ showed decreases under drought. The decrease in $g s$ is an adaptive behavior of the plant to prevent dehydration of the leaf tissue, which negatively impacted $A, C i$ and $E$ (Table 2). Even under stomatal limitation, the $\Psi w$ continued to maintain dehydration levels, indicating that the water status of sweet potato plants cultivated under drought was affected. Similar results were observed by Gajanayake and Reddy (2016). These authors, studying irrigation depths based on the replacement of water lost by evapotranspiration $(100,60,40$, and $20 \%)$, verified reductions in $A, g s$, and $E$ in sweet potato 'Beauregard'. Plants exposed to drought also showed a reduction in EiC (Table 3). Thus, the decrease observed in $A$ is linked to stomatal and biochemical limitations (Tables 2 and 3).

\section{Photosynthetic pigments}

The photosystems in plants are composed of a core complex (Chl $a$ and $\beta$-carotene) and a peripheral antenna system (Chls $a$ and $b$ and carotenoids) (Wientjes et al. 2017). In the present study, drought decreased the pigments content (Fig. 1). Drought stress-induced decrease in chlorophyll content has been reported in several plants (Jeyaramraja et al. 2005; Loutfy et al. 2012).

Plants treated with MeJA under both water regimes showed reductions in chlorophyll and carotenoids contents (Fig. 1), which possibly are not related to oxidative stress, since MDA was reduced, indicating greater cell integrity (Fig. 4a). Such results indicate that the degradation of photosynthetic pigments was due to the direct action of MeJA. This response is in agreement with those observed in Arabidopsis thaliana, where MeJA application caused a symptom similar to senescence, due to the great decline in photosynthesis and chlorophyll and a strong increase in anthocyanins and activity of antioxidant enzymes (Jung 2004).

The lower content of chlorophylls and carotenoids impairs the use and dissipation of light energy, which can result in reduced photosynthesis (Divya et al. 2018; Lapaz et al. 2019). Therefore, reduction in chlorophyll content may have contributed to the lower $A$ observed in this study (Table 1 and Fig. 1).

\section{Antioxidant pigments and phenolic compounds}

Methyl jasmonate application increased anthocyanin content under both water regimes (Fig. 2a), which corroborates results previously found in sweet potatoes (Ghasemzadeh et al. 2016) and Arabidopsis thaliana (Jung 2004). In a research carried out by Wang et al. (2013), the accumulation of anthocyanins in leaves, stems, and roots in sweet potato plants was found to play a fundamental antioxidant role in the suppression of reactive oxygen species (ROS) in plants under different abiotic stresses, which corroborates the results of this study (Figs. 2a and 4a), since the application of MeJA reduced MDA (Fig. 4a). Conversely, plants exposed to drought without application of MeJA were still under oxidative stress based on the increase in MDA (Fig. 2a), despite the increase antioxidant pigments and phenolic compounds (Figs. 3 and 4).

Beta-carotene is a nonenzymatic antioxidant produced by a wide range of plant species under stress conditions (Soares et al. 2019), capable of scavenging free radicals that damage cellular organelles (Story et al. 2010). Drought stress and MeJA 
application increased the L $\beta$-car and the $\mathrm{R} \beta$-car (Figs. 2a-b). Similar results were obtained with exogenous application of MeJA in Moringa oleifera (Saini et al. 2014). The increase in L $\beta$-car (Fig. 2a) may be related to a protection mechanism against photodamage in photosystem II (Telfer 2005) mediated by MeJA in sweet potato plants. Kang et al. (2017) verified that transgenic sweet potato plants exhibited increased tolerance to methyl viologen-mediated oxidative stress and resistance to abiotic stressors, such as salt stress, demonstrating that $\beta$-carotene plays an essential role in ROS scavenging systems and in protecting the photosynthetic machinery under conditions of oxidative and/or salt stress.

Drought regulates many key genes encoding enzymes of the phenylpropanoid pathway, such as PAL and chalcone synthase, which results in stimulated biosynthesis of phenolic compounds (Sharma et al. 2016). These compounds have antioxidative properties due their capacity to interact with ROS, but also due to their ability to serve as substrate for different peroxidases (Soares et al. 2019), hence plant cells are protected from the negative effects of oxidative stress (Wu et al. 2012). In this context, the PAL enzyme plays a crucial role at the interface between primary and secondary plant metabolism, catalyzing the first step in the biosynthetic pathway of different phenolic compounds (Ghasemzadeh et al. 2016; Sharma et al. 2016). Plants treated with MeJA showed higher PAL activity (Fig. 3e), favoring the production of nonenzymatic antioxidants, such as phenolic compounds, flavonoids, and anthocyanins, especially in plants exposed to drought (Figs. 3a-d), which reflected in lower MDA (Fig. 4a). The effects of drought on the antioxidant system of sweet potato leaves revealed a higher flavonoid content in a tolerant cultivar (Lin et al. 2006).

\section{Proline}

Proline is a small neutral amino acid and it is synthesized quickly from the glutamate and/or ornithine pathway in plant cells (Mbinda et al. 2016; Yooyongwech et al. 2013). Proline is able to neutralize, remove and/or transform ROS, allowing the management and sensing of ROS homeostasis and cellular redox balance (Soares et al. 2019). Plants exposed to drought and not treated with MeJA increased proline content in the leaf tissue, however, this effect was potentiated with MeJA application in both water regimes (Fig. 4b) and resulted in lower MDA (Fig. 4a). Previous studies have shown similar results; for example, Anjum et al. (2011) and Mahmood et al. (2012), studying the joint effects of drought and MeJA application on soybeans and bananas, respectively, verified an increase in proline and a reduction in lipid peroxidation in both control and stressed plants.

\section{Partitioned biomass production}

Plants exposed to drought reduced partitioned dry biomass production (Tables 3 and 4). This reduction can be explained by the reduction in $A$ (Table 1 ) and possibly due to the reduced mobilization of nutrients caused by the drop in $E$ (Table 1 ). Similar results were found by Yooyongwech et al. (2013) studying 15 sweet potato cultivars.

There was no positive effect of MeJA on dry biomass production, with the exception of ARDB (Table 4). Conversely, MeJA application to cauliflower seedlings significantly increased photosynthesis and chlorophyll content and promoted biomass production under water deficit stress (Wu et al. 2012). In this study, plants treated with MeJA reduced TLA and LDB, but increased ARDB (Tables 3 and 4), suggesting that the assimilated carbon was translocated for the production of adventitious roots, which resulted in less leaf expansion. It may be that, in a less severe drought condition than the one evaluated in this study, the stimulus to form adventitious roots (Table 4) in response to MeJA may be a collaborative mechanism to optimize water absorption. Application of jasmonic acid in pea cuttings increased the formation of adventitious roots in seedlings competent for rooting (Rasmussen et al. 2015). According to Fattorini et al. (2009), jasmonic acid and indolbutyric acid are involved in the success of tobacco rhizogenesis and xylogenesis.

\section{CONCLUSION}

Methyl jasmonate application in sweet potato plants affected photosynthetic performance, however it increased the production of antioxidant pigments, phenolic compounds (except L $\beta$-car under optimum water conditions), and proline. 
The evaluated response mechanisms showed that the severity of drought was more prominent than the positive effects of MeJA, since the increases on antioxidant pigments and secondary metabolites were not sufficient to mitigate stress caused by drought, which was reflected in the reduced tuberous root production.

\section{FUNDERS}

Coordenação de Aperfeiçoamento de Pessoal de Nível Superior

[http://dx.doi.org/10.13039/501100002322]

\section{AUTHOR'S CONTRIBUTION}

Conceptualization, C. H. P. Yoshida and A. C. Pacheco; Methodology, C. H. P. Yoshida and A. C. Pacheco; Software, C. H. P. Yoshida and A. M. Lapaz; Validation, C. H. P. Yoshida and A. M. Lapaz; Formal Analysis, C. H. P. Yoshida and A. M. Lapaz; Investigation, C. H. P. Yoshida, P. H. Gorni, H. F. Vítolo and S. C. Bertoli; Data Curation, C. H. P. Yoshida and A. M. Lapaz; Writing - Original Draft, C. H. P. Yoshida; Writing - Review \& Editing, A. M. Lapaz, P. H. Gorni, H. F. Vítolo, S. C. Bertoli and A. C. Pacheco; Visualization, A. M. Lapaz, Project Administration, C. H. P. Yoshida and A. C. Pacheco; Supervision, A. C. Pacheco.

\section{REFERENCES}

Albishi, T., John, J. A., Al-Khalifa, A. S. and Shahidi, F. (2013). Phenolic content and antioxidant activities of selected potato varieties and their processing by-products. Journal of Functional Foods, 5, 590-600. https://doi.org/10.1016/j.jff.2012.11.019

Anjum, S. A., Wang, L., Farooq, M., Khan, I. and Xue, L. (2011). Methyl jasmonate-induced alteration in lipid peroxidation, antioxidative defence system and yield in soybean under drought. Journal of Agronomy and Crop Science, 197, 296-301. https://doi. org/10.1111/j.1439-037X.2011.00468.x

Arnon, D. I. (1949). Copper enzymes in isolated chloroplasts. Polyphenoloxidase in Beta Vulgaris. Plant Physiology, 24, 1-15. https://doi. org/10.1104/pp.24.1.1

Bates, L. S., Waldren, R. P. and Teare, I. D. (1973). Rapid determination of free proline for water-stress studies. Plant and Soil, 39, 205207. https://doi.org/10.1007/BF00018060

Bradford, M. M. (1976). A rapid and sensitive method for the quantitation of microgram quantities of protein utilizing the principle of protein-dye binding. Analytical Biochemistry, 72, 248-254. https://doi.org/10.1016/0003-2697(76)90527-3

Craft, N. E. and Soares Junior, J. H. (1992). Relative solubility, stability and absorptivity of lutein and $\beta$-carotene in organic solvents. Journal of Agricultural and Food Chemistry, 40, 431-434. https://doi.org/10.1021/jf00015a013

Divya, P., Puthusseri, B., Savanur, M. A., Lokesh, V. and Neelwarne, B. (2018). Effects of methyl jasmonate and carotenogenic inhibitors on gene expression and carotenoid accumulation in coriander (Coriandrum sativum L.) foliage. Food Research International, 111, 11-19. https://doi.org/10.1016/j.foodres.2018.04.040

Esatbeyoglu, T., Rodríguez-Werner, M., Schlösser, A., Winterhalter, P. and Rimbach, G. (2017). Fractionation, enzyme inhibitory and cellular antioxidant activity of bioactives from purple sweet potato (Ipomoea batatas). Food Chemistry, 221, 447-456. https://doi.org/10.1016/j. foodchem.2016.10.077 
Fattorini, L., Falasca, G., Kevers, C., Rocca, L. M., Zadra, C. and Altamura, M. M. (2009). Adventitious rooting is enhanced by methyl jasmonate in tobacco thin cell layers. Planta, 231, 155-168. https://doi.org/10.1007/s00425-009-1035-y

Francis, F. J. (1982). Analysis of Anthocyanins. In P. Markakis (Eds.), Anthocyanins as food colors (p. 181-207). New York: Elsevier. https:// doi.org/10.1016/B978-0-12-472550-8.50011-1

Gajanayake, B. and Reddy, K. R. (2016). Sweetpotato responses to mid- and late-season soil moisture deficits. Crop Science, 56, 18651877. https://doi.org/10.2135/cropsci2015.03.0154

Gajanayake, B., Reddy, K. R., Shankle, M. W. and Arancibia, R. A. (2014). Growth, developmental and physiological responses of two sweetpotato (Ipomoea batatas L. [Lam]) cultivars to early season soil moisture deficit. Scientia Horticulturae, 168, 218-228. https://doi. org/10.1016/j.scienta.2014.01.018

Ghasemzadeh, A., Talei, D., Jaafar, H. Z. E., Juraimi, A. S., Mohamed, M. T. M., Puteh, A. and Halim, M. R. A. (2016). Plant-growth regulators alter phytochemical constituents and pharmaceutical quality in Sweet potato (Ipomoea batatas L.). BMC Complementary and Alternative Medicine, 16, 152. https://doi.org/10.1186/s12906-016-1113-1

Heath, R. L. and Packer, L. (1968). Photoperoxidation in isolated chloroplasts: I. Kinetics and stoichiometry of fatty acid peroxidation. Archives of Biochemistry and Biophysics, 125, 189-198. https://doi.org/10.1016/0003-9861(68)90654-1

Hiscox, J. D. and Israelstam, G. F. (1979). A method for the extraction of chlorophyll from leaf tissue without maceration. Canadian Journal of Botany, 57, 1332-1334. https://doi.org/10.1139/b79-163

Hyodo, H., Kuroda, H. and Yang, S. F. (1978). Induction of phenylalanine ammonia-lyase and increase in phenolics in lettuce leaves in relation to the development of russet spotting caused by ethylene. Plant Physiology, 62, 31-35. https://doi.org/10.1104/pp.62.1.31

Jeyaramraja, P. R., Meenakshi, S. N., Kumar, R. S., Joshi, S. D. and Ramasubramanian, B. (2005). RETRACTED: Water deficit induced oxidative damage in tea (Camellia sinensis) plants. Journal of Plant Physiology, 162, 413-419. https://doi.org/10.1016/j.jplph.2004.09.004

Jung, S. (2004). Effect of chlorophyll reduction in Arabidopsis thaliana by methyl jasmonate or norflurazon on antioxidant systems. Plant Physiology and Biochemistry, 42, 225-231. https://doi.org/10.1016/j.plaphy.2004.01.001

Kang, L., Ji, C. Y., Kim, S. H., Ke, Q., Park, S.-C., Kim, H. S., Lee, H.-U., Lee, J. S., Park, W. S., Ahn, M.-J., Lee, H.-S., Deng, X. and Kwak, S.-S. (2017). Suppression of the $\beta$-carotene hydroxylase gene increases $\beta$-carotene content and tolerance to abiotic stress in transgenic sweetpotato plants. Plant Physiology and Biochemistry, 117, 24-33. https://doi.org/10.1016/j.plaphy.2017.05.017

Lapaz, A. M., Santos, L. F. M., Yoshida, C. H. P., Heinrichs, R., Campos, M. and Reis, A. R. (2019). Physiological and toxic effects of selenium on seed germination of cowpea seedlings. Bragantia, 78, 498-508. https://doi.org/10.1590/1678-4499.20190114

Li, X., Yang, H. and Lu, G. (2018). Low-temperature conditioning combined with cold storage inducing rapid sweetening of sweetpotato tuberous roots (Ipomoea batatas (L.) Lam) while inhibiting chilling injury. Postharvest Biology and Technology, 142, 1-9. https://doi. org/10.1016/j.postharvbio.2018.04.002

Lin, K.-H., Chao, P.-Y., Yang, C.-M., Cheng, W.-C., Lo, H.-F. and Chang, T.-R. (2006). The effects of flooding and drought stresses on the antioxidant constituents in sweet potato leaves. Botanical Studies, 47, 417-426.

Loutfy, N., El-Tayeb, M. A., Hassanen, A. M., Moustafa, M. F. M., Sakuma, Y. and Inouhe, M. (2012). Changes in the water status and osmotic solute contents in response to drought and salicylic acid treatments in four different cultivars of wheat (Triticum aestivum). Journal of Plant Research, 125, 173-184. https://doi.org/10.1007/s10265-011-0419-9

Mahmood, M., Bidabadi, S. S., Ghobadi, C. and Gray, D. J. (2012). Effect of methyl jasmonate treatments on alleviation of polyethylene glycol -mediated water stress in banana (Musa acuminata cv. 'Berangan', AAA) shoot tip cultures. Plant Growth Regulation, 68, 161-169. https://doi.org/10.1007/s10725-012-9702-6 
Mbinda, W., Anami, S., Ombori, O., Dixelius, C. and Oduor, R. (2016). Efficient plant regeneration of selected Kenyan sweetpotato (Ipomoea batatas (L.) Lam.) cultivars through somatic embryogenesis. Journal of Tissue Science \& Engineering, 7, 1000176. https:// doi.org/10.4172/2157-7552.1000176

Mbinda, W., Ombori, O., Dixelius, C. and Oduor, R. (2018). Xerophyta viscosa aldose reductase, XvAld1, enhances drought tolerance in transgenic sweetpotato. Molecular Biotechnology, 60, 203-214. https://doi.org/10.1007/s12033-018-0063-x

Norastehnia, A., Sajedi, R. H. and Nojavan-Asghari, M. (2007). Inhibitory effects of methyl jasmonate on seed germination in maize (Zea mays): effect on $\alpha$-amylase activity and ethylene production. General and Applied Plant Physiology, 33, $13-23$.

Quaggio, J. A., van Raij, B. and Malavolta, E. (1985). Alternative use of the SMP-buffer solution to determine lime requirement of soils. Communications in Soil Science and Plant Analysis, 16, 245-260. https://doi.org/10.1080/00103628509367600

R Development Core Team. (2019). R: A language and environment for statistical computing. R Foundation for Statistical Computing, Vienna, Austria. [Accessed Jan. 10, 2019]. Available at: https://www.r-project.org/index.html

Rasmussen, A., Hosseini, S. A., Hajirezaei, M.-R., Druege, U. and Geelen, D. (2015). Adventitious rooting declines with the vegetative to reproductive switch and involves a changed auxin homeostasis. Journal of Experimental Botany, 66, 1437-1452. https://doi. org/10.1093/jxb/eru499

Sadler, G., Davis, J. and Dezman, D. (1990). Rapid extraction of lycopene and $\beta$-carotene from reconstituted tomato paste and pink grapefruit homogenates. Journal of Food Science, 55, 1460-1461. https://doi.org/10.1111/j.1365-2621.1990.tb03958.x

Saini, R. K., Prashanth, K. V. H., Shetty, N. P. and Giridhar, P. (2014). Elicitors, SA and MJ enhance carotenoids and tocopherol biosynthesis and expression of antioxidant related genes in Moringa oleifera Lam. leaves. Acta Physiologiae Plantarum, 36, 2695-2704. https://doi. org/10.1007/s11738-014-1640-7

Santos, H. G., Jacomine, P. K. T., Anjos, L. H. C., Oliveira, V. A., Lumbreras, J. F., Coelho, M. R., Almeida, J. A., Araujo Filho, J. C., Oliveira, J. B. and Cunha, T. J. F. (2018). Sistema Brasileiro de Classificação de Solos. 5 a edição revista e ampliada. Brasília: Embrapa.

Scholander, P. F., Bradstreet, E. D., Hemmingsen, E. A. and Hammel, H. T. (1965). Sap pressure in vascular plants. Science, $148,339-346$. https://doi.org/10.1126/science.148.3668.339

Sharma, A., Kumar, V., Thukral, A. K. and Bhardwaj, R. (2016). Epibrassinolide-imidacloprid interaction enhances non-enzymatic antioxidants in Brassica juncea L. Indian Journal of Plant Physiology, 21, 70-75. https://doi.org/10.1007/s40502-016-0203-x

Shigematsu, T., Furukawa, N., Takaoka, R., Hayashi, M., Sasao, S., Ueno, S., Nakajima, K., Kido, M., Nomura, K. and Iguchi, A. (2017). Effect of high pressure on the saccharification of starch in the tuberous root of sweet potato (Ipomoea batatas). Biophysical Chemistry, 231, 105-110. https://doi.org/10.1016/j.bpc.2017.04.012

Kuster, R. M. and Rocha, L. M. (2007). Cumarinas, cromonas e xantonas. In: C. M. O. Simões, E. P. Schenkel, G. Gosmann, J. C. P. Mello, L. A. Mentz and P. R. Petrovick (6. Ed.), Farmacognosia: da Planta ao Medicamento. UFRGS/ED. UFSC: Porto Alegre.

Soares, C., Carvalho, M. E. A., Azevedo, R. A. and Fidalgo, F. (2019). Plants facing oxidative challenges - A little help from the antioxidant networks. Environmental and Experimental Botany, 161, 4-25. https://doi.org/10.1016/j.envexpbot.2018.12.009

Springer, A., Acker, G., Bartsch, S., Bauerschmitt, H., Reinbothe, S. and Reinbothe, C. (2015). Differences in gene expression between natural and artificially induced leaf senescence in barley. Journal of Plant Physiology, 176, 180-191. https://doi.org/10.1016/j.jplph.2015.01.004

Stagos, D., Portesis, N., Spanou, C., Mossialos, D., Aligiannis, N., Chaita, E., Panagoulis, C., Reri, E., Skaltsounis, L., Tsatsakis, A. M. and Kouretas, D. (2012). Correlation of total polyphenolic content with antioxidant and antibacterial activity of 24 extracts from Greek domestic Lamiaceae species. Food and Chemical Toxicology, 50, 4115-4124. https://doi.org/10.1016/j.fct.2012.08.033

Story, E. N., Kopec, R. E., Schwartz, S. J. and Harris, G. K. (2010). An update on the health effects of tomato lycopene. Annual Review of Food Science and Technology, 1, 189-210. https://doi.org/10.1146/annurev.food.102308.124120 
Telfer, A. (2005). Too much light? How $\beta$-carotene protects the photosystem II reaction centre. Photochemical \& Photobiological Sciences, 4, 950-956. https://doi.org/10.1039/b507888c

Ueda, J. and Saniewski, M. (2006). Methyl jasmonate-induced stimulation of chlorophyll formation in the basal part of tulip bulbs kept under natural light conditions. Journal of Fruit and Ornamental Plant Research, 14, 199-210

Villordon, A., LaBonte, D. and Firon, N. (2009). Development of a simple thermal time method for describing the onset of morpho-anatomical features related to sweetpotato storage root formation. Scientia Horticulturae, 121, 374-377. https://doi.org/10.1016/j.scienta.2009.02.013

Walia, H., Wilson, C., Condamine, P., Liu, X., Ismail, A. M. and Close, T. J. (2007). Large-scale expression profiling and physiological characterization of jasmonic acid-mediated adaptation of barley to salinity stress. Plant, Cell \& Environment, 30, 410-421. https://doi. org/10.1111/j.1365-3040.2006.01628.x

Wang, A., Li, R., Ren, L., Gao, X., Zhang, Y., Ma, Z., Ma, D. and Luo, Y. (2018). A comparative metabolomics study of flavonoids in sweet potato with different flesh colors (Ipomoea batatas (L.) Lam). Food Chemistry, 260, 124-134. https://doi.org/10.1016/j.foodchem.2018.03.125

Wang, H., Fan, W., Li, H., Yang, J., Huang, J. and Zhang, P. (2013). Functional Characterization of Dihydroflavonol-4-Reductase in Anthocyanin Biosynthesis of Purple Sweet Potato Underlies the Direct Evidence of Anthocyanins Function against Abiotic Stresses. PLoS ONE, 8, e78484. https://doi.org/10.1371/journal.pone.0078484

Weidhase, R. A., Kramell, H.-M., Lehmann, J., Liebisch, H.-W., Lerbs, W. and Parthier, B. (1987). Methyljasmonate-induced changes in the polypeptide pattern of senescing barley leaf segments. Plant Science, 51, 177-186. https://doi.org/10.1016/0168-9452(87)90191-9

Wientjes, E., Philippi, J., Borst, J. W. and van Amerongen, H. (2017) Imaging the Photosystem I/Photosystem II chlorophyll ratio inside the leaf. Biochimica et Biophysica Acta (BBA) - Bioenergetics, 1858, 259-265. https://doi.org/10.1016/j.bbabio.2017.01.008

Wu, H., Wu, X., Li, Z., Duan, L. and Zhang, M. (2012). Physiological evaluation of drought stress tolerance and recovery in cauliflower (Brassica oleracea L.) seedlings treated with methyl jasmonate and coronatine. Journal of Plant Growth Regulation, 31, 113-123. https:// doi.org/10.1007/s00344-011-9224-x

Yao, X., Zhu, L., Chen, Y., Tian, J. and Wang, Y. (2013). In vivo and in vitro antioxidant activity and $\alpha$-glucosidase, $\alpha$-amylase inhibitory effects of flavonoids from Cichorium glandulosum seeds. Food Chemistry, 139, 59-66. https://doi.org/10.1016/j.foodchem.2012.12.045 Yooyongwech, S., Theerawitaya, C., Samphumphuang, T. and Cha-um, S. (2013). Water-deficit tolerant identification in sweet potato genotypes (Ipomoea batatas (L.) Lam.) in vegetative developmental stage using multivariate physiological indices. Scientia Horticulturae, 162, 242-251. https://doi.org/10.1016/j.scienta.2013.07.041

Zucker, M. (1965). Induction of phenylalanine deaminase by light and its relation to chlorogenic acid synthesis in potato tuber tissue. Plant Physiology, 40, 779-784. https://doi.org/10.1104/pp.40.5.779 


\section{SUPPLEMENTARY MATERIAL}

Table S1. Summary of analysis of variance (ANOVA) for $\mathrm{CO}_{2}$ assimilation rate $(A)$, stomatal conductance (gs), internal concentration of $\mathrm{CO}_{2}$ in the substomatic chamber $(\mathrm{Ci})$, transpiration rate $(E)$, instantaneous carboxylation efficiency $(E i C)$, water use efficiency $(W U E)$, and leaf water potential $(\Psi W)$ evaluated on the $3^{\text {rd }}, 6^{\text {th }}$, and $9^{\text {th }}$ day in sweet potato 'Beauregard' treated with two concentrations of a MeJA plant regulator [without $\left(0 \mu \mathrm{mol} \cdot \mathrm{L}^{-1}\right)$ and with $\left(13 \mu \mathrm{mol} \cdot \mathrm{L}^{-1}\right)$ application] in combination with two water regimes (normal and drought conditions, which correspond to field capacity at 100 and $40 \%$, respectively).

\begin{tabular}{|c|c|c|c|c|c|c|c|c|}
\hline Stress days & Source of variation & $A$ & gs & $\mathrm{Ci}$ & $E$ & EiC & WUE & $\Psi w$ \\
\hline \multirow{3}{*}{$3^{\text {rd }}$} & Water regimes & $\star \star \star$ & $\star \star \star *$ & $\star \star \star *$ & $\star \star \star$ & $\star \star \star$ & $\star \star$ & * \\
\hline & MeJA & * & ns & 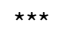 & ns & $\star \star$ & ns & ns \\
\hline & Interaction & ns & ns & ns & ns & * & ns & ns \\
\hline \multirow{3}{*}{$6^{\text {th }}$} & Water regimes & $\star \star \star$ & 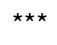 & 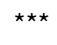 & 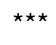 & $\star \star \star$ & $\star \star \star \star$ & 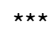 \\
\hline & MeJA & 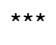 & ns & 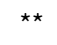 & 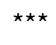 & 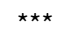 & * & ns \\
\hline & Interaction & ns & ns & ns & ns & * & * & ns \\
\hline \multirow{3}{*}{$9^{\text {th }}$} & Water regimes & $\star \star \star$ & 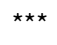 & 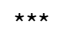 & $\star \star \star \star$ & 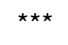 & * & * \\
\hline & MeJA & $\star \star \star$ & ns & $\star \star \star \star ~$ & $\star \star$ & $\star \star \star$ & * & ns \\
\hline & Interaction & ns & ns & ns & ns & ns & ns & $\mathrm{ns}$ \\
\hline
\end{tabular}

Significance by factorial analysis: ns, not significant; ${ }^{\star}, \mathrm{p}<0.05 ;{ }^{* \star}, \mathrm{p}<0.01 ;{ }^{* \star \star}, \mathrm{p}<0.001$.

Table S2. Summary of analysis of variance (ANOVA) for chlorophyll $a$ (Chl $a)$, chlorophyll $b(\mathrm{Chl} b)$, total chlorophyll (Tchl), carotenoids (CAR), total anthocyanin (TA), leaf $\beta$-carotene ( $L \beta$-car), and root $\beta$-carotene (R $\beta$-car) evaluated on the $9^{\text {th }}$ day in sweet potato 'Beauregard' treated with two concentrations of a MeJA plant regulator [without $\left(0 \mu \mathrm{mol} \cdot \mathrm{L}^{-1}\right)$ and with $\left(13 \mu \mathrm{mol} \cdot \mathrm{L}^{-1}\right)$ application] in combination with two water regimes (normal and drought conditions, which correspond to field capacity at 100 and $40 \%$, respectively).

\begin{tabular}{|c|c|c|c|c|c|c|c|}
\hline Source of variation & $\mathrm{Chl} a$ & $\mathrm{Chl} b$ & Tchl & CAR & TA & $L \beta$-car & $\mathrm{R} \beta$-car \\
\hline Water regimes & 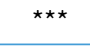 & $\star \star \star *$ & $\star \star \star$ & $\star \star \star$ & $\star \star \star \star$ & 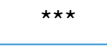 & $\star \star \star$ \\
\hline MeJA & 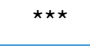 & $\star \star \star *$ & $\star \star \star \star$ & $\star \star \star \star$ & 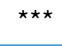 & ns & $\star \star \star$ \\
\hline Interaction & $\star \star \star$ & $\star \star \star *$ & $\star \star \star *$ & $\star \star \star$ & 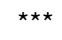 & $\star \star \star$ & $\star \star \star$ \\
\hline
\end{tabular}

Significance by factorial analysis: ns, not significant; ${ }^{* \star *}, \mathrm{p}<0.001$.

Table S3. Summary of analysis of variance (ANOVA) for total phenolic in leaf (TPL) and root (TPR), total flavonoid in leaf (TFL) and root (TFR) activity of the enzyme phenylalanine ammonia lyase (PAL), malondialdehyde (MDA), and proline evaluated on the $9^{\text {th }}$ day in sweet potato 'Beauregard' treated with two concentrations of a MeJA plant regulator [without $\left(0 \mu \mathrm{mol} \cdot \mathrm{L}^{-1}\right)$ and with $\left(13 \mu \mathrm{mol} \cdot \mathrm{L}^{-1}\right)$ application] in combination with two water regimes (normal and drought conditions, which correspond to field capacity at 100 and $40 \%$, respectively).

\begin{tabular}{|c|c|c|c|c|c|c|c|}
\hline Source of variation & TPL & TPR & TFL & TFR & PAL & MDA & Proline \\
\hline Water regimes & $\star \star \star$ & $\star \star \star *$ & $\star \star \star ~$ & $\star \star \star$ & $\star \star \star$ & 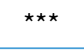 & $\star \star \star$ \\
\hline MeJA & $\star \star \star ~$ & $\star \star \star$ & $\star \star \star$ & $\star \star \star$ & $\star \star \star$ & $\star \star \star$ & $\star \star \star$ \\
\hline Interaction & 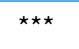 & $\star \star \star *$ & 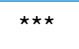 & $\star \star \star$ & $\star \star \star$ & $\star \star \star$ & 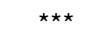 \\
\hline
\end{tabular}

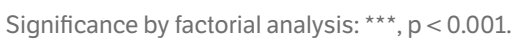

Table S4. Summary of analysis of variance (ANOVA) for total leaf area (TLA), number of tuberous root (NTU), diameter of tuberous root (DTU), leaf (LDB), steam (SDB) total shoot (TSDB), tuberous root (TUDB), adventitious root (ARDB), and total root dry biomass (TRDB) evaluated on the $9^{\text {th }}$ day in sweet potato 'Beauregard' treated with two concentrations of a MeJA plant regulator [without $\left(0 \mu \mathrm{mol} \cdot \mathrm{L}^{-1}\right)$ and with $\left(13 \mu \mathrm{mol} \cdot \mathrm{L}^{-1}\right)$ application] in combination with two water regimes (normal and drought conditions, which correspond to field capacity at 100 and $40 \%$, respectively).

\begin{tabular}{|c|c|c|c|c|c|c|c|c|c|}
\hline Source of variation & TLA & NTU & DTU & LDB & SDB & TSDB & TUDB & ARDB & TRDB \\
\hline Water regimes & $\star \star \star \star$ & * & $\star \star \star ~$ & 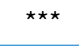 & $\star \star \star$ & 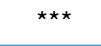 & 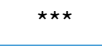 & ns & $\star \star \star$ \\
\hline MeJA & * & ns & ns & $\star \star *$ & ns & ns & ns & $\star \star$ & ns \\
\hline Interaction & ns & ns & ns & ns & ns & ns & ns & ns & ns \\
\hline
\end{tabular}

Significance by factorial analysis: $n s$, not significant; ${ }^{\star}, p<0.05 ;{ }^{\star \star}, p<0.01 ;{ }^{\star \star \star}, p<0.001$. 